\title{
Effect of System of Barley Intensification Technique on Growth Parameters of Organic Barley (Hordeum vulgare L.)
}

\author{
Victor Debbarma*, Vikram Singh and A.C. Singh \\ Department of Agronomy, Faculty of Agriculture, Sam Higginbottom University of \\ Agriculture, Technology \& Sciences, Prayagraj-211007, U.P., India \\ *Corresponding author
}

\section{A B S T R A C T}

\section{Keywords \\ Organic barley, SBI(t), Planting methods, Organic sources of nutrient and Growth parameters}

\section{Article Info}

Accepted: 15 September 2020 Available Online: 10 October 2020
The experiment was carried out during Rabi season 2015-16 and 2016-17 at Crop Research Farm, SHUATS Model of Organic Farm (SMOF), Department of Agronomy, Naini Agricultural Institute, SHUATS, Prayagraj (U.P.) to study the 'Effect of System of Barley Intensification technique on growth parameters of organic barley (Hordeum vulgare L.)'. The pooled data recorded that SBI technique has significant and highest plant height $(105.04 \mathrm{~cm})$, maximum number of tillers/ hill $(12.26)$, highest plant dry weight $(23.573 \mathrm{~g} / \mathrm{hill})$ and maximum number of effective tillers/ hill (11.28) at $90 \mathrm{DAS}$. The pooled data also recorded Kera method with significant and highest crop growth (20.703 $\mathrm{g} / \mathrm{m}^{2} /$ day) at 75 to 90 DAS intervals. Considering farm yard manure $(12 \mathrm{t} / \mathrm{ha})$ pooled data showed significantly maximum number of tillers/ hill (12.24), higher plant dry weight $(23.537 \mathrm{~g} /$ hill $)$ and maximum number of effective tillers/ hill (11.27) at 90 DAS was recorded. Further, significantly taller plant height $\left(105.09 \mathrm{~cm}\right.$ ) by $\mathrm{S}_{1}$ (Poultry manure, 2.6 t/ ha) at 90 DAS in pooled was recorded.

\section{Introduction}

Barley can be grown successfully in temperate, tropical and subtropical climatic condition of the world. It's mainly grown for food products as well as animal feed in the globe. India stands twenty second in production among barley growing countries. It produces $1.78 \mathrm{~m} \mathrm{t}$ of barley in an area of $0.66 \mathrm{~m}$ ha with the productivity of $2.67 \mathrm{t} / \mathrm{ha}$ (THE STATISTICS PORTAL, 2020). The low productivity of barley in India is mainly due to inappropriate agronomic management practices, poor soil fertility (low in organic matter), delayed sowing, short winter, improper use of production inputs (seeds and fertilizers), improper planting geometry, lodging, salt stress and terminal heat particularly in North Eastern Plain Zone of India, leading to poor crop performance and shriveled grains. Continuous uses of synthetic or inorganic fertilizers lead to deterioration of soil chemical and physical properties, biological activities and thus in general the total soil health (Mahajan et al., 2008), leading to unsustainable crop productivity (Satyanarayana et al., 2002) and environmental quality over the years. The 
System of Barley Intensification (SBI) technique is based on the principles and practices of System of Rice Intensification method of transplanting which has the potential to provide sufficient aeration, water, solar energy and available nutrients, leading to vigorous root system development from initial stage of crop growth to harvest. System of Barley Intensification technique is the system of modified agronomic management practices such as reduced seed rate, minimum use of external inputs, sowing single seed per hill, wider and square spacing, minimum use of irrigation, cono weeding or cycle weeding with reduced labours requirement, resulting in increased growth parameters and yield attributes character, thus enhanced yield of barley. Seed treatment with organic formulations like jeevamruth, cow urine and jaggery also plays an important role in early and healthy germination of seedling in SBI technique.

FYM supplies all major nutrients $(\mathrm{N}, \mathrm{P}, \mathrm{K}$, $\mathrm{Ca}, \mathrm{Mg}, \mathrm{S}$ ) including trace elements and improving soil physical, chemical and biological properties. FYM improves physical properties of soil especially the structure, water holding capacity, bulk density, porosity, cation exchange capacity, as well as, enzymatic activities were enhanced that encourages root development and yield of crops (Shekara et al., 2010). The nutrients required by the plants can be supplied through organic sources of nutrients such as farm yard manure, green leaf manure, green manure, organic foliar spray (Debbarma et al., 2015), poultry manure and bokashi manure. Application of organic manures for increasing soil fertility and crop productivity has gained importance in recent years due to speedy increasing the cost and adverse impact of continuous and indiscriminate use of synthetic fertilizers. Incorporation of organic manures has been given rise a hope to reduce the cost of cultivation and minimize adverse effects of inorganic fertilizers especially on deterioration of soil structure, soil health and environmental pollution. Utilization and scientific management of FYM, poultry manure, bokashi manure and green manures may be a good organic source for producing quality products and also maintaining environmentally-friendly sustainable agriculture. Keeping all these things in view to build healthy crop growth and to improve production the present investigation was undertaken to study the 'Effect of System of Barley Intensification technique on growth parameters of organic barley (Triticum aestivum L.)'.

\section{Materials and Methods}

The experiment was carried out during Rabi season 2015-16 and 2016-17 at Crop Research Farm, SHUATS Model of Organic Farm, Department of Agronomy, Naini Agricultural Institute, Sam Higginbottom University of Agriculture, Technology \& Sciences, Prayagraj (U.P.). SHUATS Model Organic Farm (SMOF) was developed under the National Project on Organic Farming (NPOF) by the Department of Agronomy, with Dr. Thomas Abraham, Professor (Agronomy) as its Principal Investigator. The 2 hectares ( 5 acres) area has been Certified by Lacon Quality Certification (P) Ltd. [Accreditation No. NPOP/NAB/006, Ministry of Commerce, Govt. of India] till 2017 the field was in its $9^{\text {th }}$ year of conversion. The soil of the experimental plot was sandy loam in texture, low in available nitrogen, medium in available phosphorus and high in available potash with 7.68 soil $\mathrm{pH}$. The experiment was laid out in split plot design with three replications, having three planting methods, $v i z$., System of Barley Intensification [SBI(t), $20 \times 20 \mathrm{~cm}$ ] technique, Kera method $(22.5 \times$ $10 \mathrm{~cm})$ and Furrow Irrigated Raised Bed (FIRB, $22.5 \times 10 \mathrm{~cm}$ ); three organic sources of nutrient, viz., Poultry manure $(2 \mathrm{t} / \mathrm{ha})$, 
Farm yard manure (12 t/ ha) and Bokashi manure ( $2 \mathrm{t} / \mathrm{ha})$ were studied. Green manure dhaincha (Sesbania aculeata L.) was grown during zaid season and Panchagavya was sprayed in all the treatment; and the crop seeds were treated with jeevamruth organic formulation. There were total 9 treatment combinations in all. The net plot size was $5 \times$ $4 \mathrm{~m}$ and net experimental area $540 \mathrm{~m}^{2}$. The agronomic practices, viz., weeding with cycle weeder in SBI technique, manual and hand weeding in Kera and FIRB methods were done and irrigation was given according to the schedules for all treatments.

The barley variety 'RD2035' was sown. The Meteorological data observation maximum \& minimum temperatures during the barley crop season ranged from $21.40{ }^{\circ} \mathrm{C}$ to $37.45{ }^{\circ} \mathrm{C}$ and $8.91{ }^{0} \mathrm{C}$ to $19.30{ }^{0} \mathrm{C}$, respectively in $2015-16$ and $20.15{ }^{\circ} \mathrm{C}$ to $35.52{ }^{0} \mathrm{C}$ and $7.75{ }^{\circ} \mathrm{C}$ to 15.02 ${ }^{0} \mathrm{C}$, respectively in 2016-17. Data on plant height $(\mathrm{cm})$, number of tillers/ hill, plant dry weight (g/ hill), CGR (g/ m²/ day), RGR (g/ g/ day), number of effective tillers/ hill were recorded. Data recorded on crop growth parameters were tabulated and subjected to statistical analysis as per Gomez and Gomez, 1976.

\section{Results and Discussion}

\section{Plant height (cm)}

Significantly taller plant height $(57.29,85.44$ and $105.25 \mathrm{~cm}$ in 2015-16; and 58.33, 86.74 and $104.82 \mathrm{~cm}$ in 2016-17) was recorded by $\mathrm{M}_{1}$ (System of Barley Intensification technique) at 60, 75 and 90 DAS respectively during both the years of experiments and in pooled. However, analysis of the data revealed that statistically at par by $\mathrm{M}_{2}$ (Kera method) with $\mathrm{M}_{1}$ (System of Barley Intensification technique) at 60 DAS (56.85 $\mathrm{cm})$ in 2015-16; and at 75 and 90 DAS in both the years of experiment. Data observed that $\mathrm{M}_{1}$ (System of Barley Intensification technique) significantly superior to other planting methods in both the years of experiment and in pooled.

Data also envisage that $\mathbf{M}_{3}$ (Furrow Irrigated Raised Bed) had smaller plant height at all the stages of crop growth during both the years and in pooled (Table 1). Plant height increased generally in treatment with SBI technique, might be due to wider spacing and maintained of plant population may have increased more rooting for better absorption of water and available nutrients resulting in taller plants. Similar findings were also reported by Kumar et al., (2019) in finger millet.

Data pertaining to organic sources of nutrient showed significant variation in plant height at 60, 75 and 90 DAS. It further revealed that $S_{1}$ (Poultry manure, 2 t/ ha) produced significantly taller plant height $(57.25,85.56$ and $104.97 \mathrm{~cm}$ in 2015-16; and 58.22, 87.10 and $105.20 \mathrm{~cm}$ in 2016-17) than to rest of the treatments at 60, 75 and 90 DAS during both the years and in pooled. However, analysis data observed statistically at par by $\mathrm{S}_{2}$ (Farm yard manure, $12 \mathrm{t} / \mathrm{ha}$ ) with $\mathrm{S}_{1}$ (Poultry manure, $2 \mathrm{t} / \mathrm{ha})$ at 60 and 75 DAS in 201617. Data also envisage that $\mathrm{S}_{3}$ (Bokashi manure, $2 \mathrm{t} / \mathrm{ha}$ ) had smaller plant height at all the stages of crop growth during both the years of experiment and in pooled (Table 1). Tallest plant height achieved with organic source of nutrient such as poultry manure, which could be due to sufficient availability of nutrients to crop during the growth period. These results are in agreement with the findings of Sary et al., (2014). Perusal of the data also reveals that interaction effect of planting methods and organic sources of nutrient did not affected the plant height of organic barley during both the years and in pooled. 
Table.1 Effect of planting methods and organic sources of nutrient on plant height and number of tillers of organic barley at different intervals

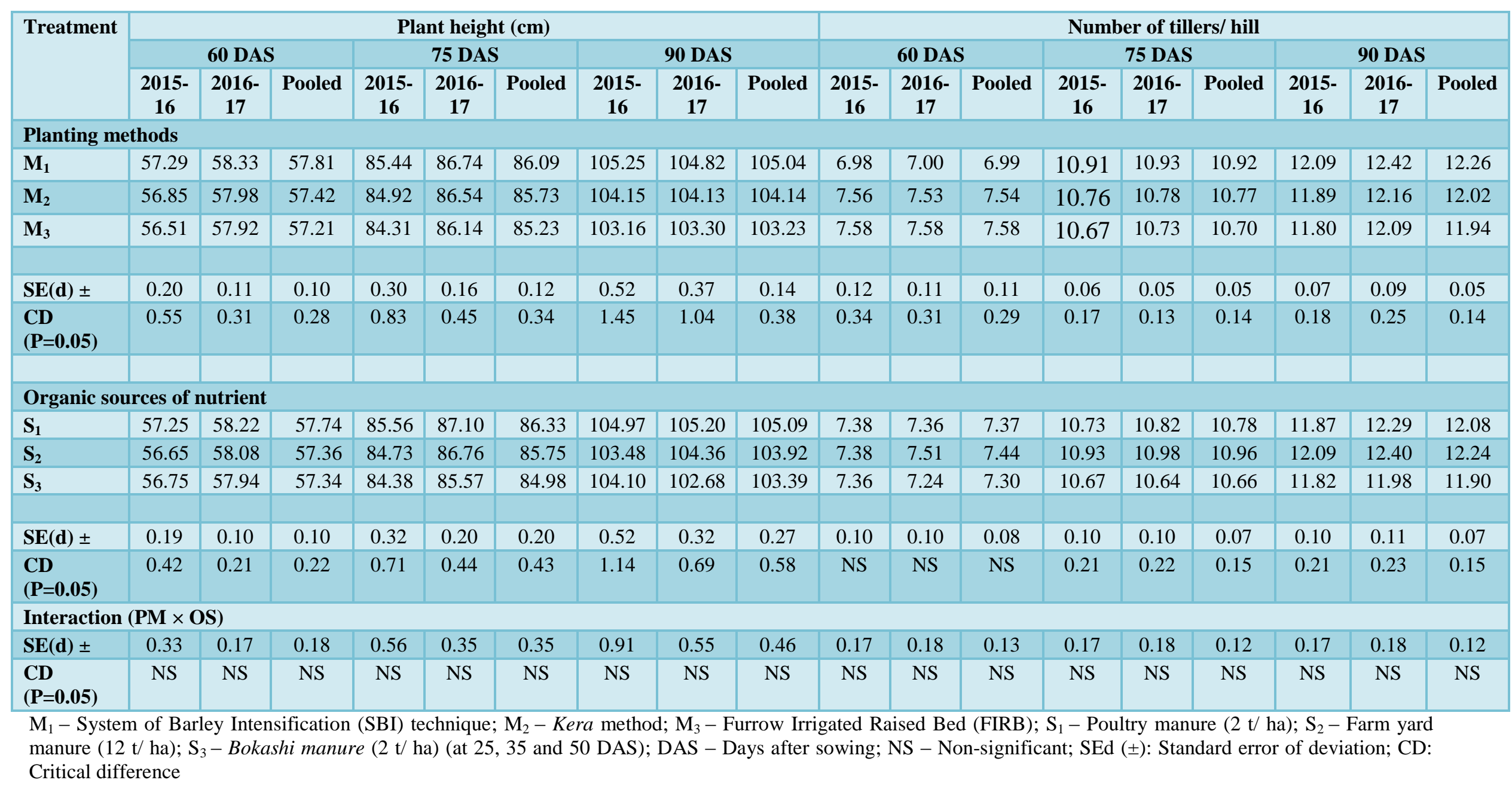


Table.2 Effect of planting methods and organic sources of nutrient on plant dry weight and CGR of organic barley at different intervals

\begin{tabular}{|c|c|c|c|c|c|c|c|c|c|c|c|c|c|c|c|c|c|c|}
\hline \multirow[t]{3}{*}{ Treatment } & \multicolumn{9}{|c|}{ Plant dry weight (g/ hill) } & \multicolumn{9}{|c|}{ Crop growth rate $\left(\mathrm{g} / \mathrm{m}^{2} / \mathrm{day}\right)$} \\
\hline & \multicolumn{3}{|c|}{60 DAS } & \multicolumn{3}{|c|}{75 DAS } & \multicolumn{3}{|c|}{90 DAS } & \multicolumn{3}{|c|}{45 to 60 DAS } & \multicolumn{3}{|c|}{60 to 75 DAS } & \multicolumn{3}{|c|}{75 to 90 DAS } \\
\hline & $\begin{array}{c}2015- \\
16\end{array}$ & $\begin{array}{c}\text { 2016- } \\
17\end{array}$ & Pooled & $\begin{array}{c}2015- \\
16\end{array}$ & $\begin{array}{c}\text { 2016- } \\
17\end{array}$ & Pooled & $\begin{array}{c}2015- \\
16\end{array}$ & $\begin{array}{c}\text { 2016- } \\
17\end{array}$ & Pooled & $\begin{array}{c}2015- \\
16\end{array}$ & $\begin{array}{c}\text { 2016- } \\
17\end{array}$ & Pooled & $\begin{array}{c}2015- \\
16\end{array}$ & $\begin{array}{c}\text { 2016- } \\
17\end{array}$ & Pooled & $\begin{array}{c}\text { 2015- } \\
16\end{array}$ & $\begin{array}{c}\text { 2016- } \\
17\end{array}$ & Pooled \\
\hline \multicolumn{19}{|c|}{ Planting methods } \\
\hline $\mathbf{M}_{1}$ & 6.939 & 6.850 & 6.895 & 16.114 & 16.631 & 16.373 & 22.615 & 24.532 & 23.573 & 9.469 & 9.210 & 9.340 & 15.291 & 16.302 & 15.797 & 10.835 & 13.168 & 12.001 \\
\hline $\mathbf{M}_{2}$ & 7.295 & 7.407 & 7.351 & 15.399 & 15.836 & 15.618 & 21.910 & 23.299 & 22.605 & 16.999 & 17.344 & 17.171 & 24.012 & 24.974 & 24.493 & 19.293 & 22.112 & 20.703 \\
\hline$M_{3}$ & 7.526 & 7.547 & 7.537 & 15.649 & 16.312 & 15.981 & 21.990 & 23.563 & 22.776 & 17.631 & 17.696 & 17.663 & 24.070 & 25.970 & 25.020 & 18.788 & 21.483 & 20.135 \\
\hline $\mathrm{SE}(\mathrm{d}) \pm$ & 0.138 & 0.195 & 0.135 & 0.139 & 0.207 & 0.143 & 0.107 & 0.278 & 0.147 & 0.466 & 0.591 & 0.380 & 0.780 & 1.080 & 0.803 & 0.485 & 0.987 & 0.702 \\
\hline $\begin{array}{l}C D \\
(P=0.05)\end{array}$ & 0.383 & 0.540 & 0.376 & 0.387 & 0.574 & 0.396 & 0.298 & 0.772 & 0.409 & 1.294 & 1.640 & 1.056 & 2.164 & 2.998 & 2.228 & 1.347 & 2.739 & 1.949 \\
\hline & & & & & & & & & & & & & & & & & & \\
\hline \multicolumn{19}{|c|}{ Organic sources of nutrient } \\
\hline $\mathbf{S}_{1}$ & 7.189 & 7.406 & 7.297 & 16.168 & 16.640 & 16.404 & 22.293 & 24.167 & 23.230 & 14.576 & 15.052 & 14.814 & 22.494 & 23.108 & 22.801 & 15.314 & 18.754 & 17.034 \\
\hline $\mathbf{S}_{\mathbf{2}}$ & 7.491 & 7.519 & 7.505 & 16.057 & 16.736 & 16.396 & 22.564 & 24.510 & 23.537 & 15.233 & 15.287 & 15.260 & 21.410 & 22.962 & 22.186 & 16.444 & 19.527 & 17.985 \\
\hline $\mathbf{S}_{3}$ & 7.080 & 6.881 & 6.980 & 14.938 & 15.404 & 15.171 & 21.658 & 22.716 & 22.187 & 14.289 & 13.911 & 14.100 & 19.468 & 21.177 & 20.323 & 17.158 & 18.482 & 17.820 \\
\hline $\mathrm{SE}(\mathrm{d}) \pm$ & 0.368 & 0.183 & 0.237 & 0.356 & 0.343 & 0.266 & 0.312 & 0.282 & 0.219 & 0.871 & 0.475 & 0.524 & 1.469 & 1.109 & 1.035 & 1.419 & 1.365 & 1.121 \\
\hline $\begin{array}{l}C D \\
(P=0.05)\end{array}$ & NS & 0.399 & NS & 0.777 & 0.747 & 0.580 & 0.681 & 0.614 & 0.477 & NS & NS & 0.471 & NS & NS & NS & NS & NS & NS \\
\hline \multicolumn{19}{|c|}{ Interaction $(\mathrm{PM} \times \mathbf{O S})$} \\
\hline $\operatorname{SE}(d) \pm$ & 0.638 & 0.317 & 0.411 & 0.617 & 0.594 & 0.461 & 0.541 & 0.488 & 0.379 & 1.508 & 0.822 & 0.908 & 2.544 & 1.921 & 1.793 & 2.458 & 2.364 & 1.942 \\
\hline $\begin{array}{l}\text { CD } \\
(P=0.05)\end{array}$ & 0.561 & NS & NS & NS & NS & NS & NS & NS & NS & NS & NS & NS & NS & NS & NS & NS & NS & NS \\
\hline
\end{tabular}

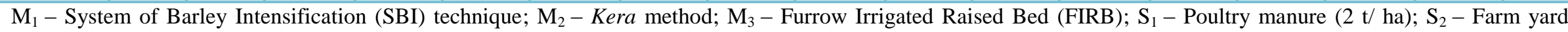

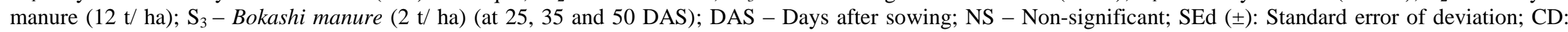

Critical difference 
Table.3 Interaction effect of planting methods and organic sources of nutrient on plant dry weight (g/ hill) of organic barley at 60, 75 and 90 DAS

\begin{tabular}{|c|c|c|c|c|c|c|c|c|c|c|c|c|}
\hline \multirow{3}{*}{$\begin{array}{l}\text { Planting } \\
\text { Methods }\end{array}$} & \multirow{2}{*}{\multicolumn{4}{|c|}{$\begin{array}{c}\text { Plant dry weight (g/ hill) at } 60 \text { DAS } \\
\text { Organic sources of nutrient }\end{array}$}} & \multirow{2}{*}{\multicolumn{4}{|c|}{$\begin{array}{c}\text { Plant dry weight (g/ hill) at } 75 \text { DAS } \\
\text { Organic sources of nutrient }\end{array}$}} & \multicolumn{4}{|c|}{ Plant dry weight (g/ hill) at 90 DAS } \\
\hline & & & & & & & & & \multicolumn{4}{|c|}{ Organic sources of nutrient } \\
\hline & $\mathbf{S}_{1}$ & $\mathbf{S}_{2}$ & $\mathbf{S}_{\mathbf{3}}$ & Mean & $\mathbf{S}_{1}$ & $\mathbf{S}_{2}$ & $\mathbf{S}_{\mathbf{3}}$ & Mean & $\mathbf{S}_{1}$ & $\mathbf{S}_{\mathbf{2}}$ & $\mathbf{S}_{\mathbf{3}}$ & Mean \\
\hline \multicolumn{13}{|l|}{$2015-16$} \\
\hline $\mathbf{M}_{1}$ & 6.831 & 7.354 & 6.633 & 6.939 & 16.343 & 16.537 & 15.461 & 16.114 & 22.906 & 23.105 & 21.834 & 22.615 \\
\hline $\mathbf{M}_{2}$ & 7.193 & 7.427 & 7.265 & 7.295 & 16.308 & 15.365 & 14.524 & 15.399 & 21.946 & 22.253 & 21.533 & 21.910 \\
\hline $\mathbf{M}_{3}$ & 7.543 & 7.693 & 7.342 & 7.526 & 15.852 & 16.267 & 14.829 & 15.649 & 22.028 & 22.336 & 21.608 & 21.990 \\
\hline Mean & 7.189 & 7.491 & 7.080 & & 16.168 & 16.057 & 14.938 & & 22.293 & 22.564 & 21.658 & \\
\hline Interaction & & $\mathrm{SE}(\mathrm{d}) \pm$ & $\mathrm{CD}(\mathrm{P}=\mathbf{0 . 0 5})$ & & & $\mathrm{SE}(\mathrm{d}) \pm$ & $\mathrm{CD}(\mathrm{P}=0.05)$ & & & $\mathrm{SE}(\mathrm{d}) \pm$ & $\mathrm{CD}(\mathrm{P}=\mathbf{0 . 0 5})$ & \\
\hline$(\mathrm{PM} \times \mathrm{OS})$ & & 0.638 & 0.561 & & & 0.617 & NS & & & 0.541 & NS & \\
\hline \multicolumn{13}{|l|}{$2016-17$} \\
\hline $\mathbf{M}_{1}$ & 6.897 & 6.948 & 6.705 & 6.850 & 16.744 & 17.010 & 16.141 & 16.631 & 24.953 & 25.131 & 23.512 & 24.532 \\
\hline $\mathbf{M}_{2}$ & 7.669 & 7.730 & 6.824 & 7.407 & 16.338 & 16.485 & 14.685 & 15.836 & 23.818 & 24.363 & 21.716 & 23.299 \\
\hline $\mathbf{M}_{3}$ & 7.651 & 7.878 & 7.113 & 7.547 & 16.839 & 16.712 & 15.386 & 16.312 & 23.730 & 24.037 & 22.921 & 23.563 \\
\hline Mean & 7.406 & 7.519 & 6.881 & & 16.640 & 16.736 & 15.404 & & 24.167 & 24.510 & 22.716 & \\
\hline Interaction & & $\mathrm{SE}(\mathrm{d}) \pm$ & $\mathrm{CD}(\mathrm{P}=0.05)$ & & & $\mathrm{SE}(\mathrm{d}) \pm$ & $\mathrm{CD}(\mathrm{P}=0.05)$ & & & $\mathrm{SE}(\mathrm{d}) \pm$ & $\mathrm{CD}(\mathrm{P}=0.05)$ & \\
\hline$(\mathrm{PM} \times \mathrm{OS})$ & & 0.317 & NS & & & 0.594 & NS & & & 0.488 & NS & \\
\hline \multicolumn{13}{|l|}{ Pooled } \\
\hline $\mathbf{M}_{1}$ & 6.864 & 7.151 & 6.669 & 6.895 & 16.544 & 16.773 & 15.801 & 16.373 & 23.930 & 24.118 & 22.673 & 23.573 \\
\hline $\mathbf{M}_{2}$ & 7.431 & 7.579 & 7.044 & 7.351 & 16.323 & 15.925 & 14.604 & 15.618 & 22.882 & 23.308 & 21.624 & 22.605 \\
\hline $\mathbf{M}_{3}$ & 7.597 & 7.786 & 7.227 & 7.537 & 16.346 & 16.490 & 15.107 & 15.981 & 22.879 & 23.186 & 22.264 & 22.776 \\
\hline Mean & 7.297 & 7.505 & 6.980 & & 16.404 & 16.396 & 15.171 & & 23.230 & 23.537 & 22.187 & \\
\hline Interaction & & $\mathrm{SE}(\mathrm{d}) \pm$ & $\mathrm{CD}(\mathrm{P}=\mathbf{0 . 0 5})$ & & & $\mathrm{SE}(\mathrm{d}) \pm$ & $\mathrm{CD}(\mathrm{P}=0.05)$ & & & $\mathrm{SE}(\mathrm{d}) \pm$ & $\mathrm{CD}(\mathrm{P}=\mathbf{0 . 0 5})$ & \\
\hline$(\mathrm{PM} \times \mathrm{OS})$ & & 0.411 & NS & & & 0.461 & NS & & & 0.379 & NS & \\
\hline
\end{tabular}

$\mathrm{M}_{1}-$ System of Barley Intensification (SBI) technique; $\mathrm{M}_{2}-$ Kera method; $\mathrm{M}_{3}-$ Furrow Irrigated Raised Bed (FIRB); $\mathrm{S}_{1}-\mathrm{Poultry}$ manure (2 t/ ha); $\mathrm{S}_{2}-$ Farm yard manure (12 t/ ha); $\mathrm{S}_{3}-$ Bokashi manure (2 t/ ha) (at 25, 35 and 50 DAS); DAS - Days after sowing; NS - Non-significant; SEd ( \pm ): Standard error of deviation; CD: Critical difference; PM - Planting methods; OS - Organic sources of nutrient. 
Table.4 Effect of planting methods and organic sources of nutrient on relative growth rate of organic barley at different intervals

\begin{tabular}{|c|c|c|c|c|c|c|c|c|c|}
\hline \multirow[t]{3}{*}{ Treatment } & \multicolumn{9}{|c|}{ Relative growth rate (g/g/day) } \\
\hline & \multicolumn{3}{|c|}{45 to 60 DAS } & \multicolumn{3}{|c|}{60 to 75 DAS } & \multicolumn{3}{|c|}{75 to 90 DAS } \\
\hline & 2015-16 & 2016-17 & Pooled & 2015-16 & 2016-17 & Pooled & 2015-16 & 2016-17 & Pooled \\
\hline \multicolumn{10}{|c|}{ Planting methods } \\
\hline $\mathbf{M}_{1}$ & 0.114 & 0.110 & 0.112 & 0.056 & 0.059 & 0.058 & 0.023 & 0.026 & 0.024 \\
\hline $\mathbf{M}_{2}$ & 0.103 & 0.104 & 0.104 & 0.050 & 0.051 & 0.050 & 0.024 & 0.026 & 0.025 \\
\hline $\mathbf{M}_{3}$ & 0.104 & 0.105 & 0.104 & 0.049 & 0.051 & 0.050 & 0.023 & 0.025 & 0.024 \\
\hline $\mathrm{SE}(\mathrm{d}) \pm$ & 0.003 & 0.003 & 0.002 & 0.002 & 0.003 & 0.002 & 0.001 & 0.001 & 0.001 \\
\hline $\mathrm{CD}(\mathbf{P}=\mathbf{0 . 0 5})$ & NS & NS & 0.005 & 0.005 & NS & 0.005 & NS & NS & NS \\
\hline \multicolumn{10}{|c|}{ Organic sources of nutrient } \\
\hline $\mathbf{S}_{1}$ & 0.107 & 0.106 & 0.106 & 0.054 & 0.054 & 0.054 & 0.021 & 0.025 & 0.023 \\
\hline $\mathbf{S}_{2}$ & 0.110 & 0.106 & 0.108 & 0.051 & 0.053 & 0.052 & 0.023 & 0.025 & 0.024 \\
\hline $\mathbf{S}_{\mathbf{3}}$ & 0.105 & 0.106 & 0.105 & 0.050 & 0.054 & 0.052 & 0.025 & 0.026 & 0.025 \\
\hline $\operatorname{SE}(d) \pm$ & 0.004 & 0.003 & 0.003 & 0.004 & 0.003 & 0.003 & 0.002 & 0.002 & 0.002 \\
\hline $\mathrm{CD}(\mathbf{P}=\mathbf{0 . 0 5})$ & NS & NS & NS & NS & NS & NS & NS & NS & NS \\
\hline \multicolumn{10}{|c|}{ Interaction $(\mathbf{P M} \times \mathbf{O S})$} \\
\hline $\mathbf{S E}(\mathbf{d}) \pm$ & 0.007 & 0.006 & 0.005 & 0.007 & 0.004 & 0.005 & 0.003 & 0.003 & 0.003 \\
\hline $\mathrm{CD}(\mathbf{P}=0.05)$ & NS & NS & NS & NS & NS & NS & NS & NS & NS \\
\hline
\end{tabular}

$\mathrm{M}_{1}$ - System of Barley Intensification (SBI) technique; $\mathrm{M}_{2}-$ Kera method; $\mathrm{M}_{3}-$ Furrow Irrigated Raised Bed (FIRB); $\mathrm{S}_{1}-$ Poultry manure (2 $\mathrm{t}$ ) ha); $\mathrm{S}_{2}-$ Farm yard manure (12 t/ ha); $S_{3}-$ Bokashi manure (2 t/ ha) (at 25, 35 and 50 DAS); DAS - Days after sowing; NS - Non-significant; SEd ( \pm ): Standard error of deviation; CD: Critical difference 
Fig.1

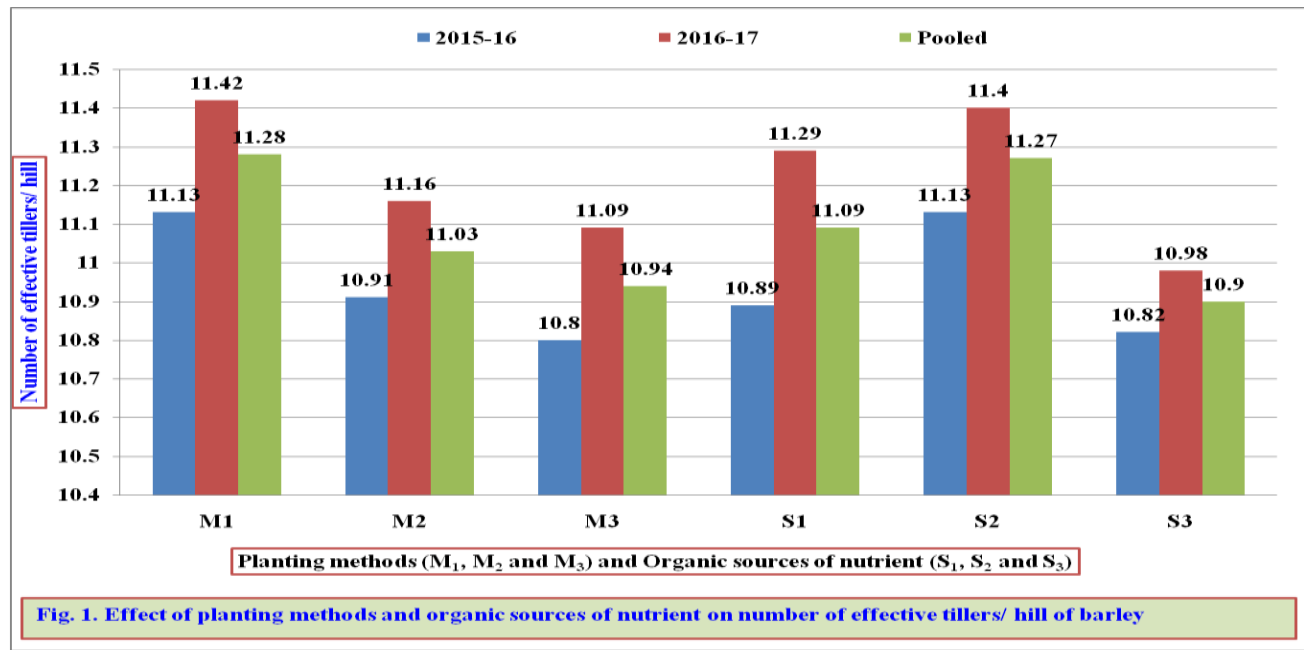

\section{Number of tillers/ hill}

The mean data recorded significant and maximum number of total tillers/ hill ( 7.58 registered with exactly same values at 60 DAS) in the treatment $\mathrm{M}_{3}$ (Furrow Irrigated Raised Bed); and by $\mathrm{M}_{1}$ (System of Barley Intensification technique) at 75 and 90 DAS in both the years of experiment and pooled. However, $\mathrm{M}_{2}$ (Kera method) was found to be at par with $\mathrm{M}_{3}$ (Furrow Irrigated Raised Bed) at 60 DAS during both the years and pooled and at 75 DAS in 2015-16. The mean data revealed that minimum number of total tillers/ hill by $\mathrm{M}_{1}$ (System of Barley Intensification technique) at 60 DAS and by $\mathrm{M}_{3}$ (Furrow Irrigated Raised Bed) at 75 and 90 DAS during both the years of experiment and in pooled (Table 1). Maximum number of tillers/ hill generally reordered with System of Barley Intensification technique, which may be due to well maintained of plant population and wider spacing. Further, this practice minimized plant density, effectively reducing inter-plant competition for light, air as well as moisture and nutrients which may have increased number of tillers/ hill. These findings are in conformity with Nyamai et al., (2012) in rice.
Among the organic sources of nutrient, $S_{2}$ (Farm yard manure, $12 \mathrm{t} / \mathrm{ha}$ ) produced more number of tillers/ hill in comparison to all other treatments at 60 DAS during both the years and in pooled, though it was found to be non significant; and it was also registered with exactly same values by $S_{1}$ (Poultry manure, 2 t/ ha) in 2015-16. The mean data also recorded significant and maximum number of tillers/ hill by $\mathrm{S}_{2}$ (Farm yard manure, $12 \mathrm{t} / \mathrm{ha}$ ) at 75 and 90 DAS in both the years of experiment and pooled. However, it was observed statistically at par by $S_{1}$ (Poultry manure, $2 \mathrm{t} / \mathrm{ha}$ ) with $\mathrm{S}_{2}$ (Farm yard manure, $12 \mathrm{t} / \mathrm{ha}$ ) at 75 DAS in both the years of experiments and at 90 DAS in 2016-17. The mean data also revealed that minimum number of total tillers/ hill by $\mathrm{S}_{3}$ (Bokashi manure, $2 \mathrm{t} / \mathrm{ha}$ ) at all the stages of crop growth during both the years of experiment and in pooled (Table 1). Maximum number of tillers with organic source of nutrient such as farm yard manure, which may be due to sufficient amount of $\mathrm{N}, \mathrm{P}, \mathrm{K}, \mathrm{S}$ and other nutrients in root zone. Further, nitrogen promotes vegetative growth through cell elongation, phosphorus is an important element for various metabolic activities and plant growth, potassium is responsible for meristematic growth, moreover regulates 
translocation of photosynthesis and action of several enzymes and sulfur for activation of enzyme, which aid in biochemical reactions and its multiplication within plant resulting more number of tillers/ hill (Prasad et al., 2019). Perusal of the data also reveals that interaction effect of planting methods and organic sources of nutrient did not affected the number of total tillers/ hill of organic barley during both the years and in pooled.

\section{Plant dry weight (g/ hill)}

Mean data registered significantly higher plant dry weight (7.526 and $7.547 \mathrm{~g}$ at 60 DAS) by $\mathrm{M}_{3}$ (Furrow Irrigated Raised Bed) during both the years of investigation and pooled. Further, mean data recorded significantly higher plant dry weight (16.114 and $16.631 \mathrm{~g}$ at $75 \mathrm{DAS} ; 22.615$ and $24.532 \mathrm{~g}$ at 90 DAS) by $M_{1}$ (System of Barley Intensification technique) during both the years of investigation and pooled, which was superior to $\mathrm{M}_{2}$ (Kera method) and $\mathrm{M}_{3}$ (Furrow Irrigated Raised Bed). However, data further revealed that $\mathrm{M}_{3}$ (Furrow Irrigated Raised Bed) was found to be statistically at par with $\mathrm{M}_{2}$ (Kera method) at 75 DAS in 2016-17 and pooled. Further, it was registered by $\mathrm{M}_{2}$ (Kera method) to be statistically at par with $\mathrm{M}_{3}$ (Furrow Irrigated Raised Bed) at 60 DAS in 2015-16 and pooled (Table 2 and Table 3). Higher plant dry weight with System of Barley Intensification technique which might have induced both greater and deeper root growth, thereby contributing to increased nutrient uptake throughout the crop cycle (Barison and Uphoff, 2011).

Among the different organic sources of nutrient significant influence on plant dry weight was recorded at 75 and 90 DAS during both the years of experiment and in pooled. Further, $\mathrm{S}_{2}$ (Farm yard manure, 12 t/ ha) produced significantly more plant dry weight at 75 DAS in 2016-17 and at 90 DAS in
2016-17 and pooled; and by $S_{1}$ (Poultry manure, 2 t/ ha) at 75 DAS in 2015-16 and pooled and at 90 DAS in 2015-16. The mean data also recorded highest plant dry weight at 60 DAS in 2015-16 and pooled, though it was found to be non significant. Further, it was observed significantly plant dry weight at 60 DAS in 2016-17. However, $S_{2}$ (Farm yard manure, $12 \mathrm{t} / \mathrm{ha}$ ) was found to be statistically at par with $S_{1}$ (Poultry manure, $2 \mathrm{t} / \mathrm{ha}$ ) in 2015-16 and pooled; and $S_{1}$ (Poultry manure, $2 \mathrm{t} / \mathrm{ha}$ ) with $\mathrm{S}_{2}$ (Farm yard manure, $12 \mathrm{t} / \mathrm{ha}$ ) in 2016-17 at 75 DAS and at 60 DAS in 2016-17. Data further, revealed that $S_{1}$ (Poultry manure, $2 \mathrm{t} / \mathrm{ha}$ ) was found to be statistically at par with $\mathrm{S}_{2}$ (Farm yard manure, $12 \mathrm{t} / \mathrm{ha}$ ) at 90 DAS in 2016-17 and pooled; by $S_{2}$ (Farm yard manure, 12 t/ ha) and $S_{3}$ (Bokashi manure, 2 t/ ha) with $\mathrm{S}_{1}$ (Poultry manure, 2 t/ ha) in 2015-16 (Table 2 and Table 3). Significantly higher plant dry weight with organic source of nutrient might be due to the stimulation effect of farm yard manure on improving the soil physical properties, increasing soil productivity and supplying higher amount of nutrients demand to plants uptake, which in turn improving the vegetative growth and dry matter production resulting higher plant dry weight. These findings are in corroboration with Sary et al., (2014) and Ahmad et al., (2012).

Appraisal of the data on plant dry weight significantly interacts with planting methods and organic sources of nutrient at 60 DAS in 2015-16. An examine of the data, clearly indicated that $\mathrm{M}_{1} \mathrm{~S}_{2}$ (System of Barley Intensification technique + Farm yard manure, 12 t/ ha), $\mathrm{M}_{2} \mathrm{~S}_{1}$ (Kera method + Poultry manure, 2 t/ ha), $\mathrm{M}_{2} \mathrm{~S}_{2}$ (Kera method + Farm yard manure, $12 \mathrm{t} / \mathrm{ha}$ ), $\mathrm{M}_{2} \mathrm{~S}_{3}$ (Kera method + Bokashi manure, $2 \mathrm{t} / \mathrm{ha}), \mathrm{M}_{3} \mathrm{~S}_{1}$ (Furrow Irrigated Raised Bed + Poultry manure, $2 \mathrm{t} / \mathrm{ha}$ ) and $\mathrm{M}_{3} \mathrm{~S}_{3}$ (Furrow Irrigated Raised Bed + Bokashi manure, 2 t/ ha) were found to be at par with $\mathrm{M}_{3} \mathrm{~S}_{2}$ (Furrow Irrigated 
Raised Bed + Farm yard manure, 12 t/ ha) at 60 DAS in 2015-16 (Table 2). Perusal of the data also reveals that interaction effect of planting methods and organic sources of nutrient did not affected the plant dry weight of organic barley during both the years and in pooled at 60 and 70 DAS of plant growth.

\section{Crop Growth Rate (g/ m²/ day)}

The data indicate that in general, there was an increase in the crop growth rate, irrespective of treatments and thereafter, a gradual reduction in crop growth rate was recorded of the crop. A close scrutiny of mean data on crop growth rate revealed that the planting methods exerted significant influence on crop growth rate at 45 to 60,60 to 75 and 75 to 90 DAS intervals during both the years and in pooled. The maximum crop growth rate (19.293 and $22.112 \mathrm{~g} / \mathrm{m}^{2} /$ day) was recorded by $\mathrm{M}_{2}$ (Kera method) at 75 to 90 DAS intervals respectively in both the years and pooled. The mean data also recorded significantly higher crop growth rate (17.631 and $24.070 \mathrm{~g} / \mathrm{m}^{2} /$ day in $2015-16$; and 17.696 and $25.970 \mathrm{~g} / \mathrm{m}^{2}$ /day in 2016-17 respectively) by $\mathrm{M}_{3}$ (Furrow Irrigated Raised Bed) at 45 to 60 and 60 to 75 DAS intervals in both the years and pooled. However, $\mathrm{M}_{2}$ (Kera method) was observed to be statistically at par with $\mathrm{M}_{3}$ (Furrow Irrigated Raised Bed) at 45 to 60 and 60 to 75 DAS intervals in both the years and pooled. Further, data also revealed that $\mathrm{M}_{3}$ (Furrow Irrigated Raised Bed) was observed to be statistically at par with $\mathrm{M}_{2}$ (Kera method) at 75 to 90 DAS intervals during both the years and pooled. A close examine of mean data indicated that $M_{1}$ (System of Barley Intensification technique) with lowest crop growth rate at all the stages of crop growth intervals during both the years of experiment and in pooled (Table 2). CGR generally increased rapidly to a peak between flag leaf emergence and heading and then declined to zero just prior to soft dough stage. The dry matter loss of the crop at the end of the season may be attributed to negative net photosynthesis over the period of increasing moisture stress (Karimi and Siddique, 1991). This would be concluded from evidence that a sizeable fraction of carbohydrate is used for respiration, particularly with soil moisture stress at the end of the season (Davidson and Campbell, 1983).

Among the organic sources of nutrient $S_{2}$ (Farm yard manure, $16 \mathrm{t} / \mathrm{ha}$ ) was recorded highest crop growth rate $(0.139$ and $15.233 \mathrm{~g} /$ $\mathrm{m}^{2} /$ day 2015-16; 0.142 and $15.287 \mathrm{~g} / \mathrm{m}^{2} /$ day in 2016-17) at 45 to 60 DAS intervals respectively in comparison to other organic sources of nutrient during both the years and in pooled; and in 2016-17 and pooled at 75 to 90 DAS intervals, though it was found to be non significant at these growth intervals. The mean data also recorded highest crop growth rate by $S_{1}$ (Poultry manure, $2 \mathrm{t} / \mathrm{ha}$ ) at 60 to 75 DAS intervals during both the years and pooled, though it was found non significant. The mean data also registered highest crop growth rate by $\mathrm{S}_{3}$ (Bokashi manure, $2 \mathrm{t} / \mathrm{ha}$ ) at 75 to 90 DAS intervals in 2015-16 and found non significant. Further, significant and higher crop growth rate was recorded by $S_{2}$ (Farm yard manure, $16 \mathrm{t} / \mathrm{ha}$ ) at 40 to 60 DAS intervals in pooled. However, $\mathrm{S}_{1}$ (Poultry manure, 2 t/ ha) was observed to be statistically at par with $\mathrm{S}_{2}$ (Farm yard manure, $16 \mathrm{t} / \mathrm{ha}$ ) at 45 to 60 DAS intervals in pooled analysis (Table 2). Appraisal of the data on crop growth rate did not showed interaction between planting methods and organic sources of nutrient at different intervals of organic barley during both the years and in pooled.

\section{Relative growth rate (g/ g/ day)}

A steady but marginal decrease in RGR was observed during the successive growth 
intervals. Data revealed that highest RGR (0.024 and $0.026 \mathrm{~g} / \mathrm{g} / \mathrm{day})$ at 75 to $90 \mathrm{DAS}$ intervals in the treatment $\mathrm{M}_{2}$ (Kera method) in both the years and pooled, where $\mathrm{M}_{1}$ (System of Barley Intensification technique) was registered with exactly same values with $\mathrm{M}_{2}$ (Kera method) in 2016-17, though it was registered no significance difference. The data also recorded highest RGR in the treatment $\mathrm{M}_{1}$ (System of Barley Intensification technique) at 45 to 60 DAS intervals in both the years and in 2016-17 at 60 to 75 DAS intervals, though it was found to be non significant. Significant and highest relative growth rate was observed in pooled at 45 to 60 DAS intervals and in 2015-16 and pooled at 60 to 75 DAS intervals (Table 4).

Among the organic sources of nutrient highest on relative growth rate $(0.025$ and $0.026 \mathrm{~g} / \mathrm{g} /$ day at 75 to 90 DAS intervals) was recorded in the treatment $\mathrm{S}_{3}$ (Bokashi manure, $3 \mathrm{t} / \mathrm{ha}$ ) at 75 to 90 DAS intervals in both the years and pooled, though it was found no significance difference. The mean data also recorded highest on relative growth rate by $\mathrm{S}_{2}$ (Farm yard manure, $12 \mathrm{t} / \mathrm{ha}$ ) at 45 to $60 \mathrm{DAS}$ intervals in both the years and pooled and found non significant. Data also registered with exactly same values by $S_{1}$ (Poultry manure ( $2 \mathrm{t} / \mathrm{ha})$ and $\mathrm{S}_{3}$ (Bokashi manure (2 t/ ha) with $S_{2}$ (Farm yard manure, $12 \mathrm{t} / \mathrm{ha}$ ) at 45 to 60 DAS intervals in 2016-17. Data further revealed that, $S_{1}$ (Poultry manure $(2 \mathrm{t} / \mathrm{ha})$ with highest on relative growth rate of 0.054 g/ g/ day registered with exactly same values in both the years and pooled, where $\mathrm{S}_{3}$ (Bokashi manure ( $2 \mathrm{t} / \mathrm{ha}$ ) was registered with exactly same values in 2016-17 and found non significant (Table 4). It was observed from the perusal of data that interaction effect of planting methods and organic sources of nutrients did not affect the relative growth rate of organic barley during both the years and in pooled.

\section{Number of effective tillers/ hill (at 90 DAS)}

Perusal of the mean data showed significant variation in number of effective tillers/ hill among different planting methods at 90 DAS. Maximum number of effective tillers/ hill (11.13 and 11.42) was recorded by $\mathrm{M}_{1}$ (System of Barley Intensification technique) in both the years of experiment and in pooled. Data also envisage that $M_{3}$ (Furrow Irrigated Raised Bed) had minimum number of effective tillers/ hill during both the years and in pooled (Fig. 1). Maximum number of effective tillers realized with System of Barley Intensification technique may be due to the better concurrent utilization of moisture, nutrients and solar radiation as well as orientation of the leaves, thereby leading to greater amount of photosynthesis, which increases the expression of effective tiller. This finding is supported by Suryawanshi $e t$ al., (2013); and Mithilesh and Abraham (2017) in wheat.

Data pertaining to organic sources of nutrient showed significant variation in number of effective tillers/ hill at 90 DAS. It further revealed that $S_{2}$ (Farm yard manure, $12 \mathrm{t} / \mathrm{ha}$ ) produced significantly maximum number of effective tillers/ hill (11.13 and 11.40) than all the other treatments during both the years and in pooled. However, $S_{1}$ (Poultry manure, $2 \mathrm{t} /$ ha) remained at par to $S_{2}$ (Farm yard manure, $12 \mathrm{t} / \mathrm{ha}$ ) in 2016-17 and pooled. Data also envisage that $\mathrm{S}_{3}$ (Bokashi manure, $2 \mathrm{t} / \mathrm{ha}$ ) had minimum number of effective tillers/ hill during both the years of experiments and in pooled (Fig. 1). Maximum number of effective tillers recorded with organic source of nutrient such as farm yard manure, which may have supplied available plant nutrient directly to plants and created favorable soil environment, thus increased the available nutrient and water-holding capacity of soil for longer time resulting increased number of effective tillers (Sarma et al., 2007). Similar 
cause and effect was also found by Gupta et al., (2006); Kumar and Abraham (2018) in wheat. It is clear from the data that interaction effect of planting methods and organic sources of nutrient did not affect the number of effective tillers/ hill of organic barley during both the years and in pooled.

The results of two year study of organic barley demonstrate that System of Barley Intensification (SBI) technique, with the principles and practices of System of Rice Intensification (SRI) method of transplanting is more beneficial than other planting methods. The application of farm yard manure has been found to be the best for obtaining vigorous and healthy growth character of barley than the application of other organic sources of nutrient.

\section{References}

Ahmad, G., Mahdi, B., Yasser, E., Abolfazl, T. and Ahmad, A. (2012). The effect of cattle manure and chemical fertilizer on yield and yield component of barley (Hordeum vulgare). African J. of Agri. Res. 7(3): 504-508.

Ahmed, R., Karima and Hassan, A.M.A. (2019). Effect of planting method on barley productivity, water saving and nutrient use efficiency under El-Minia conditions. Middle East Journal of Agriculture Research 8(3): 788-796.

Barison, Joeli and Uphoff, Norman (2011). Rice yield and its relation to root growth and nutrient-use efficiency under SRI and conventional cultivation: an evaluation in Madagascar. Paddy Water Environ. 9:65-78.

Davidson, H.R. and Campbell, C.A. (1983). Effect of temperature, moisture and nitrogen on the rate of development of spring wheat as measured by degree days. Can. J. Plant Sci. 63: 833-46.
Debbarma, Victor, Abraham, Thomas, Debbarma, Salpa and Debbarma, Hamari (2015). Influence of different planting methods and organic nutrients on growth and yield of rice [Oryza sativa (L.) sub sp. japonica]. The Ecoscan, 9(3\&4): 1039-1044.

Gomez, K.A. and Gomez, A.A. (1976). Three or more factor experiment. (In:) Statistical Procedure for Agricultural Research $2^{\text {nd }}$ ed., pp.139 -141.

Gupta, V., Sharma, R.S. and Vishwakarma, S.H. (2006). Long-term effect of integrated nutrient management on sustainability and soil fertility of rice (Oryza sativa) - wheat (Triticum aestivum) cropping system. Indian Journal of Agronomy 51(3): 160-164.

Karimi M.M. and Siddique, K.H.M. (1991). Crop growth and relative growth rates of old and modern wheat cultivars. Aust. J, Agric. Res. 42: 13-20.

Kumar, Sandeep and Abraham, Thomas (2018). Productivity Potential of Wheat under Certified Organic Production System. International Journal of Current Microbiology and Applied Sciences 7(10): 281-288.

Kumar, Praveen, A., Parasuraman, P., Sivagamy, K. and Sivakumar, B. (2019). Growth, yield and economics of irrigated finger millet as influenced by system of finger millet intensification (SFI) practices in north eastern zone of Tamil Nadu. Journal of Pharmacognosy and Phytochemistry 8(3): 660-663.

Mahajan, A., Bhagat, R.M. and Gupta, R.D. (2008). Integrated nutrient management in sustainable rice-wheat cropping system for food security in India, SAARC Journal of Agriculture 6(2): 29-32.

Mithilesh and Abraham, Thomas (2017). Agronomic Evaluation of Certified Organic Wheat (Triticum aestivum L.). 
International Journal of Current Microbiology and Applied Sciences 6(7): 1248-1253.

Nyamai, M., Mati, B.M., Home, P.G., Odongo, B., Wanjogu, R. and Thuranira, E.G. (2012). Improving land and water productivity in basin rice cultivation in Kenya through System of Rice Intensification (SRI). Agric. Eng. Int: CIGR Journal 14(2): 1-13.

Prasad, Jasvir, Thomas, Tarence, Bharosre, Ram and Mir, Ahmad, Zahoor (2019). Effect of organic and inorganic source of nutrients on growth and yield of barley (Hordeum vulgare L.). Journal of Pharmacognosy and Phytochemistry 8(2): 521-523.

Sarma, A., Singh, H. and Nawal, R.K. (2007). Effect of integrated nutrient management on productivity of wheat (Triticum aestivum) under limited and adequate irrigation supplies. Indian Journal of Agronomy 52(2): 120-123.

Satyanarayana, V., Prasad, Vara, P.V., Murthy, V.R.K. and Boote, K.J. (2002). Influence of integrated use of farmyard manure and inorganic fertilizers on yield and yield components of irrigated lowland rice. Journal of Plant Nutrition 25(10): 2081-2090.

Sary, G.A., El-Deepah, H.R.A., El-Gizawy, N.K.H.B., Gobarah, E., Mirvat,
Tawfik, M.M. and Howida, H., Khedr (2014). Impact of Organic Manures and Foliar Spraying with Micronutrients on Growth, Yield and Yield Components of Barley Grown in Newly Reclaimed Sandy Soil. American-Eurasian J. Agric. \& Environ. Sci. 14(11): 1130-1140.

Suryawanshi, P.K., Patel, J.B. and Kumbhar, N.M. (2013). Yields and economics of wheat (Triticum aestivum L.) influenced by SWI techniques with varying nitrogen levels. International Journal of Agricultural Sciences 9(1): 305-308.

Shekara, B.G., Sharnappa and Krishnamurthy, N. (2010). Effect of irrigation schedules on growth and yield of aerobic rice (Oryza sativa) under varied levels of farmyard manure in Cauvery command area. Indian Journal of Agronomy 55(1): 35-39.

THE STATISTICS PORTAL (2020). Production volume of barley in India $F Y$ 2012-2020. https://www.statista.com/statistics/878 245/india-production-volume-ofbarley/ and https://www.statista.com/statistics/874 036/india-area-harvested-for-barleyproduction/, accessed on Aug 10, 2020.

\section{How to cite this article:}

Victor Debbarma, Vikram Singh and Singh, A.C. 2020. Effect of System of Barley Intensification Technique on Growth Parameters of Organic Barley (Hordeum vulgare L.). Int.J.Curr.Microbiol.App.Sci. 9(10): 1914-1926. doi: https://doi.org/10.20546/ijcmas.2020.910.234 